\title{
Pemanfaatan Limbah Kulit Kopi sebagai Upaya Pemberdayaan Ibu-ibu Rumah Tangga di Desa Latimojong, Kabupaten Enrekang
}

\section{(Utilization of Coffe Skin (Exocarp) Waste as an Effort to Empower Housewives in Latimojong Village, Enrekang District)}

\author{
Andi Nur Fajri Suloi ${ }^{1 *}$, Nurul Fitriani Syam ${ }^{1}$, Nurlaela Jufri ${ }^{1}$, Rosnita Sari ${ }^{2}$, \\ Meta Mahendradatta ${ }^{1}$ \\ 1 Departemen Teknologi Pertanian, Fakultas Pertanian, Universitas Hasanuddin, \\ Jl. Perintis Kemerdekaan Km. 10 Makassar 90245 \\ 2 Departemen Sastra Prancis, Fakultas Ilmu Budaya, Universitas Hasanuddin, \\ Jl. Perintis Kemerdekaan Km. 10 Makassar 90245 \\ *Penulis Korespondensi: nurfajrisuloi@gmail.com \\ Diterima Juli 2018/Disetujui Agustus 2019
}

\begin{abstract}
ABSTRAK
Desa Latimojong, Kecamatan Buntu Batu merupakan salah satu daerah penghasil kopi terbesar di Kabupaten Enrekang. Pengolahan biji kopi memberikan hasil samping berupa kulit kopi yang berpotensi menjadi limbah. Alternatif solusi yang dapat dilakukan adalah mengolah limbah kulit kopi tersebut menjadi sebuah produk berupa bubuk kulit kopi yang dapat dimanfaatkan oleh masyarakat, khususnya ibu-ibu rumah tangga sebagai bahan pewarna atau pemberi aroma pada produk pangan. Program ini bertujuan untuk memberdayakan para ibu rumah tangga melalui pemanfaatan limbah kulit kopi. Metode yang digunakan ialah penyuluhan dan demonstrasi dengan beberapa tahapan, yaitu pra kegiatan, sosialisasi, pelaksanaan, dan evaluasi kegiatan.Hasil dari pelaksanaan kegiatan ini ialah meningkatkan pengetahuan dan keterampilan masyarakat tentang pengolahan limbah kulit kopi, menghasilkan suatu produk yang berasal dari limbah kulit kopi, serta memberikan nilai ekonomis pada kulit kopi.
\end{abstract}

Kata kunci: bubuk, ibu rumahtangga, kulit kopi, pemberdayaan

\begin{abstract}
The Village of Latimojong, Sub-district of Buntu Batu is one of the largest coffee producing areas in Enrekang Regency. Coffee bean processing gives a by-product in the form of coffee husk which has the potential to become waste. Alternative solutions that can be done is to process the coffee skin waste into a product in the form of coffee skin powder that can be used by the community, especially housewives as coloring agents or scents in food products. This program aims to empower housewives through the utilization of coffee skin waste. The method used is counseling and demonstration with several stages, namely pre-activity, socialization, implementation, and evaluation of activities. The results of the implementation of this activity is to increase community knowledge and skills about processing coffee skin waste, producing a product derived from coffee skin waste, and provide economic value to the skin of the coffee.
\end{abstract}

Keywords: coffee husk, empowerment, housewife, powder

\section{PENDAHULUAN}

Indonesia merupakan salah satu negara penghasil kopi terbesar keempat di dunia setelah Brazil, Vietnam, dan Kolombia (ICO 2017). Kopi merupakan salah satu hasil komoditas perkebunan yang memiliki nilai ekonomis cukup tinggi di antara tanaman perkebunan lainnya seperti kakao dan teh. Selain berperan penting sebagai sumber devisa negara, kopi juga merupakan sumber penghasilan bagi satu setengah juta jiwa petani kopi di Indonesia (Rahardjo 2012).
Penghasil kopi di Indonesia terpusat di beberapa wilayah, salah satunya, yaitu Desa Latimojong, Kecamatan Buntu Batu, Kabupaten Enrekang (Thamrin et al. 2015). Terletak di lereng Pegunungan Latimojong dengan luas daerah $19,98 \mathrm{~km}^{2}$ dan jumlah penduduk mencapai 3.030 jiwa (BPS Enrekang 2018). Sementara itu, jumlah lahan kopi Kecamatan Buntu Batu seluas 2.077 ha dengan jumlah produksi sebanyak 1.823 ton. Data ini menunjukkan bahwa hasil tersebut cukup besar dibandingkan dengan daerah penghasil kopi lain di Kabupaten Enrekang, yaitu 
Kecamatan Baroko dengan jumlah 1.638 ton. Tingginya hasil produksi kopi di Desa Latimojong, Kecamatan Buntu Batu berpotensi untuk meningkatkan kesejahteraan bagi para penduduknya.

Sejauh ini pengolahan kopi yang dilakukan di Kecamatan Buntu Batu, khususnya di Desa Latimojong masih sebatas pengupasan kulit buah hingga menjadi produk akhir berupa kopi bubuk, Potensi kulit buah kopi sebagai bahan pangan yang kaya antioksidan masih terabaikan (Marcelinda et al. 2016). Antioksidan yang terkandung dalam kulit kopi, yaitu polifenol berupa antosianin, tanin, plavonol, flavan 3-ol, asam hidraksinat, dan kafrin (Esquivel \& Jimenes 2012). Saat ini limbah kopi hanya dimanfaatkan sebagai pakan ternak dan pupuk organik saja (Prasetyo 2015).

Kebanyakan masyarakat Desa Latimojong sendiri saat ini menyia-nyiakan limbah kulit kopi dengan langsung membuang hasil penggilingan kopi ke drainase. Perilaku ini mengakibatkan meluasnya polusi organik pencemaran limbah. Dampak lingkungan berupa polusi organik limbah kopi yang paling berat ialah pada perairan di mana effluen kopi dikeluarkan. Hal ini dikarenakan subtansi organik limbah ini bersifat lamban terlarut dalam air limbah, sehingga menyebabkan kondisi anaerobik (Juwita et al. 2017). Sementara itu, dampak sederhana yang dapat ditimbulkan oleh kondisi ini, yaitu bau busuk yang cepat muncul karena kulit kopi masih memiliki kandungan air cukup tinggi, yakni 75-80\%. Hal ini mempermudah pertumbuhan mikrob pembusuk (Simanihuruk et al. 2010).

Upaya memanfaatkan limbah pengolahan kopi menjadi produk yang memiliki nilai ekonomi sekaligus mengatasi polusi bau busuk perlu dilakukan. Solusi yang ditawarkan adalah program peningkatan kapasitas masyarakat untuk memproduksi produk alternatif berupa bubuk kulit kopi sebagai bahan tambahan pangan yang berfungsi sebagai pewarna, penambah rasa manis, penambah aroma, maupun bahan minuman. Program ini dirancang berbentuk pendampingan untuk ibu-ibu rumah tangga.

\section{METODE PELAKSANAAN KEGIATAN}

\section{Waktu dan Tempat}

Kegiatan ini dilakukan selama tiga bulan mulai bulan April-Juli 2018 di Desa Latimojong, Kecamatan Buntu Batu, Kabupaten Enrekang, Sulawesi Selatan.

\section{Khalayak Sasaran}

Sasaran dari kegiatan ini ialah ibu-ibu rumah tangga Desa Latimojong, Kecamatan Buntu Batu, Kabupaten Enrekang.

\section{Alat dan Bahan}

Alat yang digunakan pada program ini adalah blender kering, baskom, ayakan, nampan, sendok, kemasan, dan kantong teh. Bahan utama yang digunakan adalah kulit kopi.

\section{Prosedur Kerja Pembuatan Bubuk Kulit Kopi}

Kulit/ceri kopi yang telah matang (berwarna merah) dan telah dipisahkan dari bijinya disortir dan dicuci hingga bersih. Kemudian dikeringkan di bawah sinar matahari atau menggunakan oven hingga kering sempurna dan mengeluarkan bau khas kopi (Putri 2017). Setelah kering, dihaluskan menggunakan blender lalu diayak dengan ayakan 80 mesh. Bubuk halus yang didapatkan digunakan sebagai bahan tambahan pangan, sementara bubuk kasar dapat diseduh seperti teh (Gambar 1).

\section{Bentuk Kegiatan}

Bentuk kegiatan secara keseluruhan mencakup persiapan program, sosialisasi, dan pelaksanaan (kegiatan terdiri atas tiga tahap, yaitu go desa dan course day sebagai bentuk penyuluhan, serta bukan kupi action sebagai bentuk demonstrasi dan pelatihan), dan evaluasi kerja.

\section{Metode Pengumpulan dan Analisis Data}

Metode pengumpulan data pada program ini adalah wawancara dan tes uraian singkat berupa

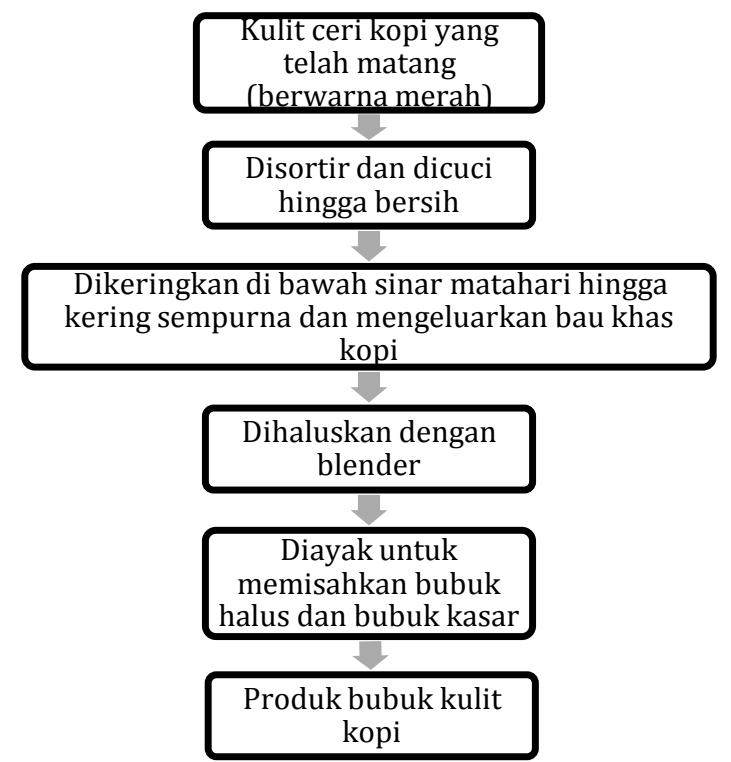

Gambar 1 Diagram alir pembuatan bubuk kulit kopi. 
pre-test dan post-test yang berisi 12 poin pertanyaan terkait pengetahuan masyarakat setempat mengenai pengolahan limbah kulit kopi dan manfaatnya. Responden yang digunakan dalam pengumpulan data merupakan ibu-ibu rumah tangga berjumlah 21 orang responden. Rancangan yang digunakan adalah rancangan pretest-posttest kelompok tunggal (one group pretest-posttest design) dengan satu jenis sasaran tanpa adanya kelompok kontrol atau pembanding (Irmayadi 2017). Analisis data dilakukan dengan metode deskriptif kuantitatif.

\section{HASIL DAN PEMBAHASAN}

\section{Penyuluhan dan Demonstrasi Pembuatan Bubuk Kulit Kopi}

\section{- Penyuluhan}

Tujuan diadakannya kegiatan penyuluhan adalah untuk meningkatkan pengetahuan sasaran tentang potensi limbah kopi, sistem pengolahan limbah kopi, manfaat limbah kopi bagi kesehatan, serta kandungan gizi yang dimiliki limbah kopi. Oleh karena itu, diadakan sosialisasi dan peyuluhan mengenai sistem pengolahan limbah kopi, manfaat dari kulit kopi serta pemanfaatan dan pengolahannya menjadi bubuk kulit kopi yang dibawakan oleh penyuluh pertanian Kecamatan Buntu Batu dan ketua pelaksana. Kegiatan penyuluhan ini diikuti dengan aktif oleh seluruh peserta yang dapat dilihat dari antusiasnime dan diskusi dua arah antara para peserta dan tim pelaksana setelah pemberian materi.

\section{- Demonstrasi}

Demonstrasi pengolahan limbah kulit kopi menjadi produk bubuk kulit kopi dilakukan oleh mahasiswa Universitas Hasanuddin sebagai pelaksana kegiatan (Gambar 2). Sebelum demonstrasi dilakukan, mahasiswa yang bertindak sebagai narasumber menjelaskan kepada seluruh peserta tentang proses pembuatan bubuk kulit kopi. Selama pemberian arahan juga dilakukan diskusi berhubungan dengan produk bubuk kulit kopi tersebut.

Setelah demonstrasi singkat oleh pelaksana, masyarakat setempat mencoba sendiri membuat bubuk kulit kopi (Gambar 3). Pada saat itu juga, dilakukan demonstrasi langsung pemanfaatan bubuk instan kulit kopi. Gambar 4 menunjukkan kreasi peserta dalam membuat kue dengan menggunakan produk bubuk kulit kopi sebagai bahan tambahan pangan. Peserta dibagi dalam tiga kelompok. Kue yang telah dibuat masing-

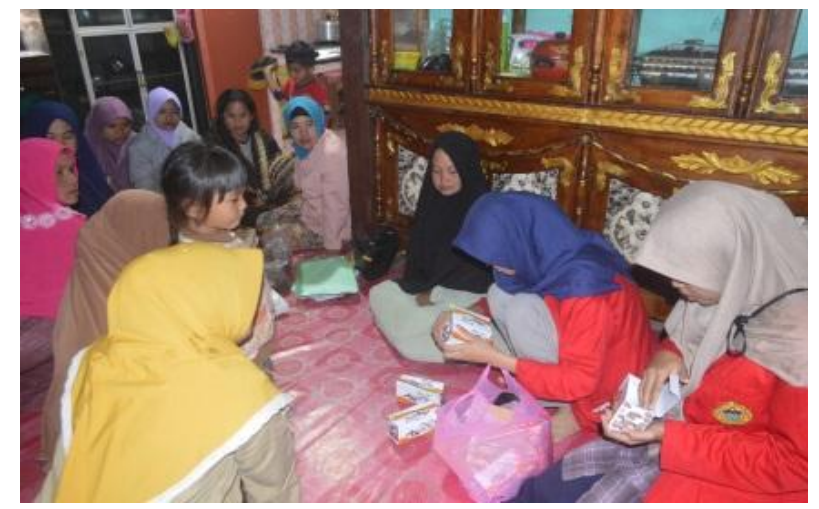

Gambar 2 Penjelasan narasumber dan demonstrasi pembuatan produk bubuk kulit kopi.

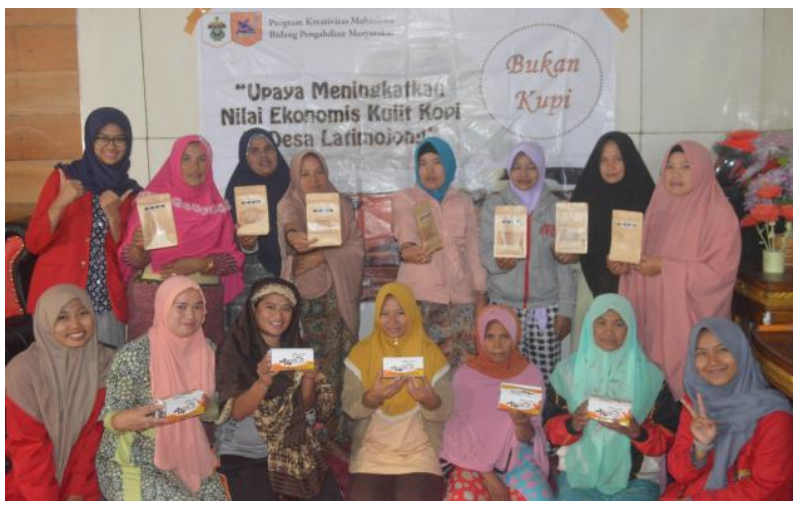

Gambar 3 Produk bubuk kulit kopi.
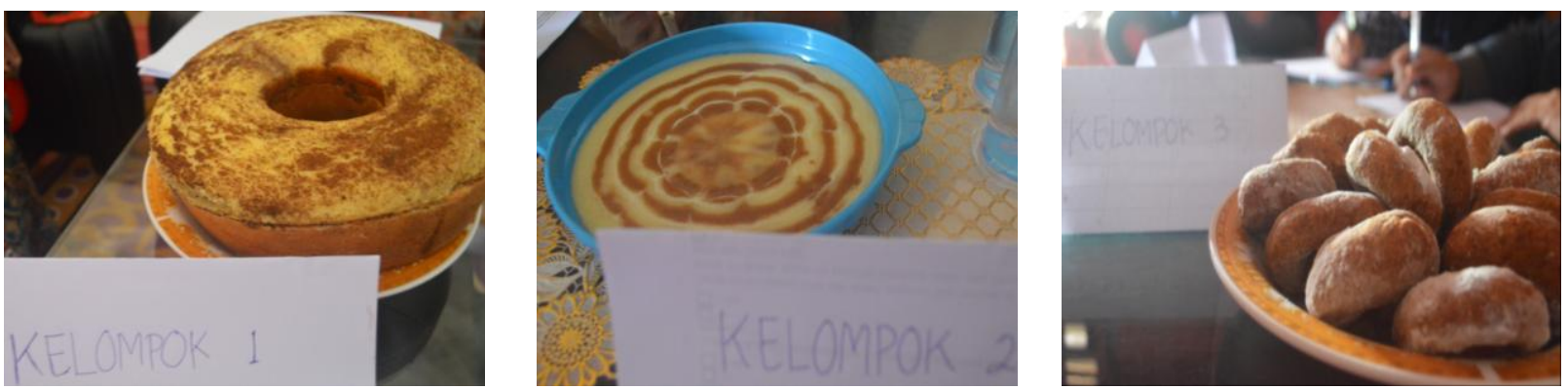

Gambar 4 Kreativitas masyarakat dalam membuat kue dengan produk bubuk kulit kopi sebagai bahan tambahan pangan. 
masing kelompok kemudian disajikan untuk dicicipi dan dinilai berdasarkan cita rasa, penampilan, dan kreativitas.

\section{Tingkat Pengetahuan dan Keterampilan Masyarakat tentang Pemanfaatan Limbah Kulit Kopi}

Tingkat pengetahuan sasaran tentang potensi dan pemanfaatan limbah kopi sebelum kegiatan penyuluhan perlu dilakukan guna mendapatkan gambaran tentang pengetahuan dasar sasaran serta mengetahui efektivitas dari kegiatan penyuluhan. Cara untuk mengukur tingkat pengetahuan tersebut adalah dengan menggunakan instrumen pre-test yang berisi sejumlah pertanyaan tentang pemanfaatan kulit kopi dan keberadaan sistem pengolahan kulit kopi di Desa latimojong. Instrumen pre-test berisi 12 pertanyaan dan harus dijawab dengan jujur oleh sasaran.

Pada akhir kegiatan, 12 pertanyaan yang telah diberikan sebelum kegiatan penyuluhan diberikan lagi kepada sasaran sebagai bentuk evaluasi post-test. Dengan adanya post-test tersebut, tingkat efektivitas penyerapan sasaran terhadap materi dan kegiatan pengabdian dapat diketahui. Berdasarkan hasil pre-test yang dilakukan sebelum kegiatan, diketahui bahwa tingkat pengetahuan dan keterampilan masyarakat tentang pemanfaatan limbah kulit kopi hanya sekitar 18,75\%, sedangkan pada post-test yang dilakukan setelah semua program selesai meningkat hingga 81,25\%. (Gambar 5). Hasil tersebut menunjukkan bahwa program ini telah berhasil menambah wawasan dan ilmu pengetahuan bagi masyarakat setempat.

\section{Evaluasi dan Upaya Keberlanjutan Program}

Hasil evaluasi program secara umum menunjukkan bahwa masyarakat sasaran telah mampu mengolah sendiri limbah kulit kopi menjadi bubuk kulit kopi yang dapat digunakan sebagai bahan tambahan pangan. Gambar 6 menunjukkan masyarakat sasaran juga berkomitmen untuk terus melanjutkan program ini. Hampir seluruh peserta sebanyak 97,6\% sasaran menyatakan ingin terus memproduksi bubuk kulit kopi untuk konsumsi keluarga maupun untuk dijual. Sasaran juga berharap dapat membentuk suatu usaha ekonomi yang memanfaatkan limbah kulit kopi.
Persentase hasil pre-test dan post-test

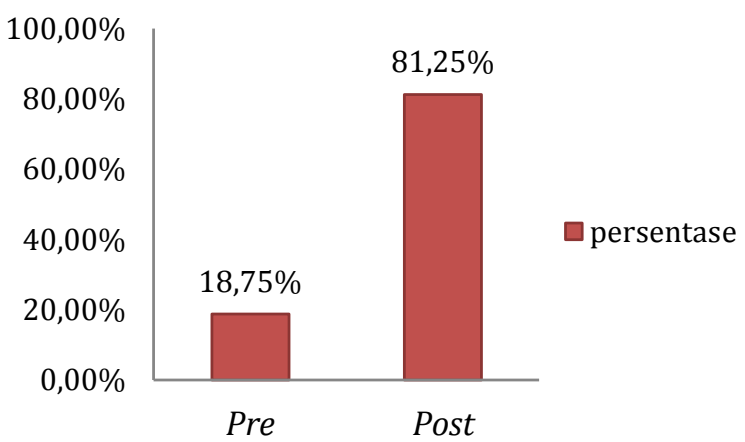

Gambar 5 Diagram hasil pre-test dan post-test.

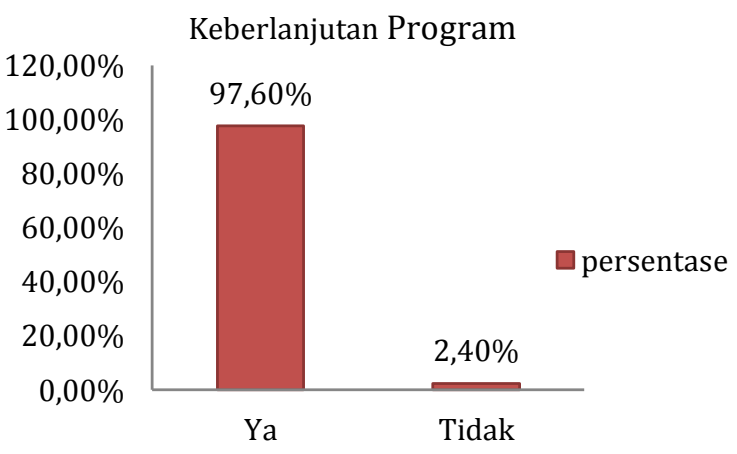

Gambar 6 Diagram komitmen masyarakat untuk tetap membuat produk bubuk kulit kopi.

\section{SIMPULAN}

Melalui program pemberdayaan masyarakat ini, masyarakat Desa Latimojong telah ditingkatkan kapasitas keterampilannya membuat produk olahan dari limbah kulit kopi, aksesnya terhadap manfaat kenaikan nilai ekonomis kulit kopi, dan kontribusinya mengatasi permasalahan limbah yang ada. Masyarakat sasaran telah berkomitmen untuk mengembangkan produk olahan limbah kulit kopi. Oleh karenanya, tugas pemerintah setempat selanjutnya adalah memberikan dukungan berupa fasilitas dan insentif agar usaha ekonomi produk lokal ini dapat terwujud.

\section{UCAPAN TERIMA KASIH}

Ucapan terima kasih disampaikan kepada Belmawa-Kemenristekdikti yang telah memberikan pendanaan melalui Program Kreativitas Mahasiswa (PKM), Universitas Hasanuddin, 
dosen pembimbing yang telah memberikan dukungan, masyarakat Desa Latimojong khususnya para ibu rumah tangga sebagai mitra dalam program ini, Pemerintah Desa Latimojong, Kecamatan Buntu Batu, Kabupaten Enrekang yang telah memberikan izin dan mempersiapkan segala sarana dan prasarana, serta segala pihak yang telah membantu dalam pelaksanaan program ini.

\section{DAFTAR PUSTAKA}

Esquivel P, Jimenez VM. 2012. Functional Properties of Coffe by Producetst. Food Research International. 46: 488-495. https:// doi.org/10.1016/j.foodres.2011.05.028

[ICO] International Coffe Organization. 2017. Annual Review 2015-2016. International Coffe Organization. London (UK): International Coffe Organization.

Irmayadi TP. 2017. Penerapan Model problem Based Leraning (PBL) untuk Meningkatkan Kebiasan Menerapkan Pengetahuan Masa Lalu dengan Situasi Konsep Pencemaran Lingkungan. [Skripsi]. Bandung: Universitas Pasundan.

Juwita A, Mustafa A, Tamrin R. 2017. Studi Pemanfaatan Kulit Kopi Arabika (Coffe Arabica L.) sebagai Mikro Organisme Lokal (MOL).Agrointek. 11(1): 1-8. https://doi.org/ 10.21107/agrointek.v11i1.2937
[BPS] Badan Pusat Statistik Kabupaten Enrekang. Kecamatan Buntu Batu Dalam Angka 2018. [Internet]. [diunduh 2019 Agustus 02]. Tersedia pada: https://enrekangkab.bps.go .id/publication/download.html.

Marcelinda A, Ridhay A, Prismawiyanti. 2016. Aktivitas Antioksidan Ekstrak Limbah Kulit Ari Biji Kopi (Coffea sp) berdasarkan Tingkat Kepolaran Pelarut. Journal of Natural Science 5(1): 21-30.

Prasetyo H. 2015. Ekstraksi Senyawa Antioksidan Kulit Buah Kopi: Kajian Jenis Kopi Dan Lama Maserasi. [Skripsi]. Jember (ID): Universitas Jember.

Putri RA. 2017. Pengembangan Pasar Minuman Cascara Ready to Drink dengan Pendekatan Riset Aksi. [Skripsi]. Bogor: Institut Pertanian Bogor.

Rahardjo P. 2012. Panduan Budidaya dan Pengolahan Kopi Arabika dan Robusta. Jakarta (ID): Penebar Swadaya.

Simanihuruk, Kiston, Sirait J. 2010. Silase Kulit Buah Kopi Sebagai Pakan Dasar pada Kambing Boerka Sedang Tumbuh. Disampaikan pada: Seminar Nasional Teknologi Peternakan dan Veteriner. Sumatera Utara (ID) 2010.

Thamrin S, Slamet H, Dwijono HD, Jamhari. 2015. Efisiensi Teknis Usaha Tani Kopi Arabika di Kabupaten Enrekang. Jurnal Ilmu Pertanian. 18(2): 92-97. https://doi.org/10.22146/ ipas.9090 